\title{
MicroRNA-139, an Emerging Gate-Keeper in Various Types of Cancer
}

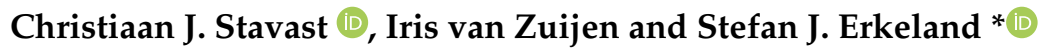

Citation: Stavast, C.J.; van Zuijen, I.; Erkeland, S.J. MicroRNA-139, an Emerging Gate-Keeper in Various Types of Cancer. Cells 2022, 11, 769. https://doi.org/10.3390/ cells11050769

Academic Editors: César LópezCamarillo, Macrina B. Silva-Cázares and Carlos Pérez Plasencia

Received: 2 February 2022 Accepted: 19 February 2022 Published: 22 February 2022

Publisher's Note: MDPI stays neutral with regard to jurisdictional claims in published maps and institutional affiliations.

Copyright: (C) 2022 by the authors. Licensee MDPI, Basel, Switzerland. This article is an open access article distributed under the terms and conditions of the Creative Commons Attribution (CC BY) license (https:// creativecommons.org/licenses/by/ $4.0 /)$.
Department of Immunology, Erasmus MC University Medical Center, 3015 GD Rotterdam, The Netherlands; c.stavast@erasmusmc.nl (C.J.S.); i.vanzuijen@erasmusmc.nl (I.v.Z.)

* Correspondence: s.erkeland@erasmusmc.nl; Tel.: +31-107-044-651

\begin{abstract}
Mounting data show that MIR139 is commonly silenced in solid cancer and hematological malignancies. MIR139 acts as a critical tumor suppressor by tuning the cellular response to different types of stress, including DNA damage, and by repressing oncogenic signaling pathways. Recently, novel insights into the mechanism of MIR139 silencing in tumor cells have been described. These include epigenetic silencing, inhibition of POL-II transcriptional activity on gene regulatory elements, enhanced expression of competing RNAs and post-transcriptional regulation by the microprocessor complex. Some of these MIR139-silencing mechanisms have been demonstrated in different types of cancer, suggesting that these are more general oncogenic events. Reactivation of MIR139 expression in tumor cells causes inhibition of tumor cell expansion and induction of cell death by the repression of oncogenic mRNA targets. In this review, we discuss the different aspects of MIR139 as a tumor suppressor gene and give an overview on different transcriptional mechanisms regulating MIR139 in oncogenic stress and across different types of cancer. The novel insights into the expression regulation and the tumor-suppressing activities of MIR139 may pave the way to new treatment options for cancer.
\end{abstract}

Keywords: MIR139; cancer; tumor suppressor; transcriptional regulation; microRNAs

\section{Introduction}

MiRNAs are small non-coding RNAs (19-22 nt) and post-transcriptionally regulate the expression of target mRNAs involved in cell proliferation and differentiation, stress responses and the prevention of oncogenesis [1-3]. Almost all primary miRNA transcripts (pri-miRNAs) are transcribed by RNA Polymerase II and commonly contain a $5^{\prime}$ cap and, in most cases, a poly-A tail [4] (for reviews, see [5-8]). The pri-miRNAs form a hairpin structure and are cleaved by the RNase III enzyme DROSHA that is bound to RNA binding protein DiGeorge syndrome chromosome region 8 (DGCR8) into a premature miRNA (pre-miRNA) [9-11]. The pre-miRNA is transported to the cytoplasm by Exportin-5 (XPO5), where the hairpin is cleaved by the RNase III enzyme DICER and stabilized by transactivation-responsive RNA binding protein (TRBP) [12-16]. Only one of the two miRNA strands, either miRNA-5p or miRNA-3p, is then loaded by the RNA-induced silencing complex (RISC) loading complex (RLC) into RISC [17-21], which consists of Argonaute 2 (AGO2), DICER, TRBP, proteins of the Glycine-Tryptophan protein of $182 \mathrm{kDa}$ (GW182) family, such as trinucleotide repeat-containing gene 6A-6C (TNRC6A-TNRC6C), and the carbon catabolite repressor 4-negative on TATA (CCR4-NOT) complex [22-28]. Nucleotides $2-7$ at the $5^{\prime}$ end of the miRNA, the seed region, are critical for target binding specificity on the $3^{\prime}$ UTR of target transcripts $[7,23,29]$. The activities of miRNAs are highly cell-type- and cellular-state-dependent $[30,31]$. There is strong evidence for miRNA functions in stress responses [3]. MIR139 is an example of a stress-responsive gene. Silencing of MIR139 is critical for the oncogenic transformation of cells. The role for $m i R-139$ in the diagnosis and prognosis of cancer is described in the following reviews [32,33]. Here, we discuss the 
recent findings regarding the transcriptional and post-transcriptional regulation of MIR139 in cellular stress conditions. Furthermore, we discuss some of the major oncogenic targets that are regulated by $m i R-139$.

\section{Genomic Localization and Host Gene PDE2A}

MIR139, encoding miR-139-5 $p$ and miR-139-3p, is a well-conserved miRNA located on human chromosome 11q13.4 in intron-1 of the Phosphodiesterase 2A (PDE2A) gene. PDE2A is an essential cAMP-cGMP hydrolyzing enzyme and is a signal transducer in different cellular processes [34-36]. Genomic deletion of Pde2a in mice (B6; 129P2-Pde2A $<$ tm1Dgen $>/ H$; EM: 02366) is embryonically lethal and mutant mice die in utero at embryonic day (E) 15.5 [37]. In addition, despite multiple attempts of our research team, mice with a genomic deletion of the putative Pde $2 a$ promoter could not be generated, indicating that Pde $2 a$ is essential for survival [38]. In agreement, other investigators have found that Pde $2 a \mathrm{KO}$ embryos display lethal defects in fetal liver development and hematopoiesis [39]. Livers from Pde2a KO embryos (E14.5) displayed an increased level of cleaved Caspase-3, expressed decreased levels of anti-apoptotic protein BCL2 and contained Annexin-V-positive apoptotic cells compared to heterozygous and wild-type (WT) littermates [39]. In addition, in Pde2a-deficient fetal livers, the development of myeloid and erythroid lineages is impaired [39]. However, the Pde $2 a$ deficiency does not affect the colony-forming capacity of myeloid progenitors, indicating that PDE2A is dispensable for the expansion and maturation of hematopoietic progenitors.

Despite a significant correlation between the expression of PDE2A and MIR139 in lung cancer cell lines [40], we and other investigators have shown that $m i R-139-5 p$ and /or $m i R-$ 139-3p expression is not correlated to PDE2A expression levels in leukemia [38], gastric [41] and colorectal cancer cells [42]. We have recently shown that MIR139 expression is strongly silenced in MLL-AF9 AML, whereas the expression of Pde2a was not affected [38]. These data indicate that post-transcriptional mechanisms other than splicing and subsequent processing of pri-miR-139 by the microprocessor complex play a role in the stability and processing of $m i R-139-5 p$ and $m i R-139-3 p$. In agreement, a transcriptional start site (TSS) of MIR139 was established on pri-miR-139 by rapid amplification of cDNA ends (5'-RACE) in gastric SGC-7901 cells, which is 2327 base pairs upstream of the pre-miR-139 (Figure 1A) [41]. Together, these data indicate that MIR139 is regulated, at least in part, independently of $P D E 2 A$. The different mechanisms involved in transcriptional and post-transcriptional MIR139 regulation are discussed below. An overview of the different in vitro and in vivo models used to study MIR139 in cancer can be found in Table 1.

Table 1. Overview of experimental models used for functional MIR139 investigation in the various types of cancer.

\begin{tabular}{|c|c|c|}
\hline Experimental Model & Type of Cancer, Cell Types & References \\
\hline MIR139 KO mice & Bone marrow, T-cells and colon & {$[38,43,44]$} \\
\hline Ercc1 KO mice & Bone marrow, Fanconi anemia & [45] \\
\hline Mouse 32D cells & AML & [45] \\
\hline $\begin{array}{c}\text { Mouse MLL-AF9 leukemia and human AML cell lines MOLM-13, THP-1, MV4-11, HL-60, HEL } \\
\text { and U937, Kasumi-1, SKNO-1 }\end{array}$ & MLL-AF9 AML, AML & {$[38,46]$} \\
\hline $\begin{array}{c}\text { Human AML and CML, AML cell lines NB4, HP-1, KG-1a, OCI-AML3, U937, HL-60 Human } \\
\text { T-ALL cell lines HPB-ALL, TALL-1, KOPTK1, Jurkat, CCRF-CEM, Molt16 }\end{array}$ & Diverse types of leukemia & [47-51] \\
\hline $\begin{array}{l}\text { Colon cancer cell lines HT29, SW480, SW620, KM12, SW116, HCT116, HCT-8, HCT-116, LoVo, } \\
\text { Caco2, DLD1, LS180, NCM460, HcoEpic and Human colon cancer in NOD/SCID mice }\end{array}$ & Colon cancer & {$[42,52-61]$} \\
\hline $\begin{array}{l}\text { Human lung cancer cells, H460, IC11LC13, NSCLC cell lines A549, H1299, H1975, HCC827, } \\
\text { H1650, H460, SK-MES-1 and SPC-A-1, PM2.5-treated mice }\end{array}$ & Lung cancer & {$[40,62-65]$} \\
\hline Diabetes mouse model, Streptozotocin-injected Kunming mice & Blood cells, liver & [66] \\
\hline $\begin{array}{l}\text { Patient-derived glioma stem-like cells, Human glioma cell lines LN229, A172, SHG44, T98G, U87 } \\
\text { and U251, BALB/c nude mice }\end{array}$ & Glioma & {$[67-69]$} \\
\hline Primary Human Ovarian cancer, cell lines A2780, SKOV3, OVCAR3 and OV90 & Ovarian cancer & {$[70-72]$} \\
\hline SGC-7901, MKN-45 and AGS & Gastric cancer & [41] \\
\hline SW1990, BxPC-3, PANC-1 and AsPC-1 & Pancreatic cancer & [73] \\
\hline $\begin{array}{l}\text { HepG2, PLC/PRF/5, MHCC97L and SM. Human HCC cell lines (SK-Hep-3B, HepG2, } \\
\text { HCC-LM3) and MHCC97-HMC-7721 }\end{array}$ & Liver cancer & {$[74,75]$} \\
\hline Cell lines RC-4B/C (CRL-1903) and GH3 (CCL-82.1) & Pituitary adenomas & [76] \\
\hline Cell line SNU46 & Laryngeal squamous cell carcinoma & [77] \\
\hline Human cell lines K1, IHH-4, BCPAP and TCP1 & Papillary thyroid carcinoma & [78] \\
\hline
\end{tabular}


A)

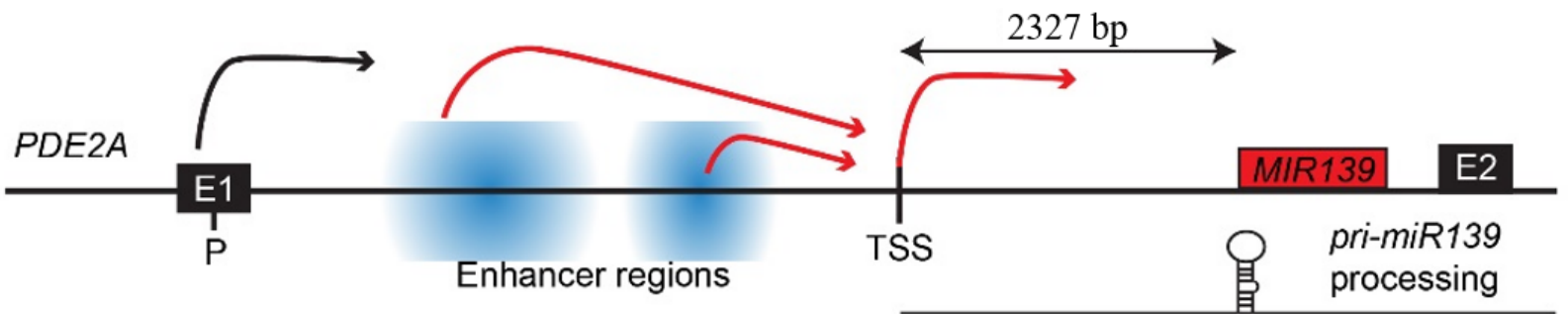

B)

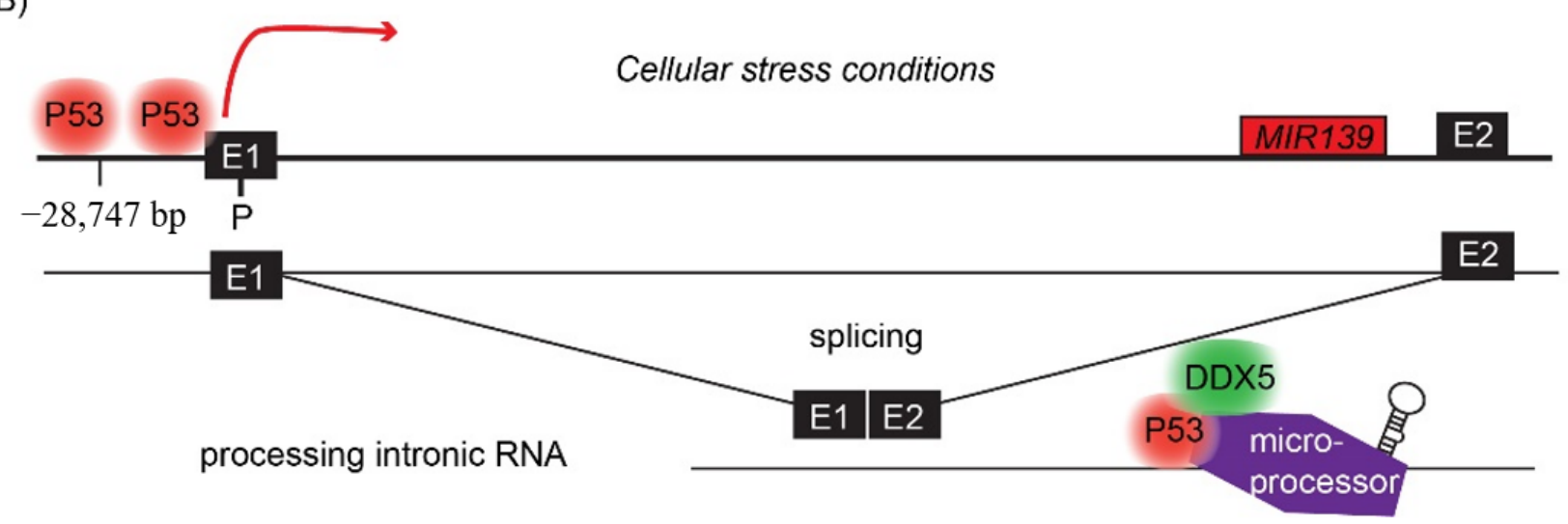

Figure 1. Overview of the transcriptional regulation of MIR139. (A) Schematic representation of the PDE2A locus (chr11: 72,605,000-72,644,500) with the promoter (P), transcriptional start site of MIR139 (TSS), the first two exons of PDE2A (E1 and E2), enhancer regions (in blue) and MIR139 (red box). The transcription of $P D E 2 A$ is indicated by the black arrow. The enhancer regions are critical for MIR139 transcription (red arrows). (B) Schematic overview of the model in which, under cellular stress conditions, p53 binds to the PDE2A promoter and stimulates transcription (red arrow) and processing of pri-miR-139.

\section{MIR139 Is Induced by p53-Mediated Cellular Stress Response}

The level of $m i R-139-3 p$, but not miR-139-5p, is elevated in hematopoietic stem and progenitor cells (HSPCs) of Fanconi anemia patients and in HSPCs of nucleotide excision repair gene Ercc1-deficient mice [45]. Elevated miR-139 levels in these cells are a direct result of interstrand DNA crosslinks (ICLs) and cause apoptosis [45]. In agreement, treatment of normal HSPCs with ICL-inducing agent Mitomycin C induces miR-139-3p expression. This effect is counteracted by increased miR-199 expression in these cells [45]. Blocking of $m i R-139-3 p$ with antagomirs rescues HSPC expansion in colony assays, demonstrating the relevance of $m i R-139-3 p$ for ICL-mediated bone marrow failure. The expression of $m i R-139-3 p$ is undetectable in Fanconi AML cells, suggesting that MIR139 silencing is an oncogenic driver event that allows for the acceptance of high oncogenic stress levels in the affected cells, which ultimately leads to the transformation of pre-leukemic Fanconi myeloid progenitor cells towards AML [45]. We showed that p53 is responsible for ICLinduced bone marrow failure and that loss of p53 drives leukemogenesis in this model [45]. The loss of p53 coincided with the loss of miR-139 expression in Ercc1-deficient leukemia cells. This result suggests that MIR139 expression is regulated by the tumor suppressor p53.

A well-conserved p53-responsive element ( $p 53 R E$ ) is mapped at the -28,747 bp position downstream of MIR139 (Figure 1B), which was experimentally confirmed by ChIP experiments with human lung carcinoma cells after p53 induction [52]. Treatment of lung cancer cell lines with Inauhzin-C, a p53-activating compound, induces MIR139 expression only in p53-positive cells, but not in p53 $\mathrm{KO}$ cells [52]. In the human colon cell line HT29-tsp53 expressing a temperature-sensitive variant of murine p53 (V135A), miR-139-5p 
and $m i R-139-3 p$ were both rapidly upregulated at the permissive temperature, as well as the expression of PDE2A [53,54]. P53 binds to the promoter of PDE2A (Figure 1B), which may explain the correlation of $m i R-139$ levels with the increased expression of the PDE2A gene. A different study of colorectal cancer presents evidence for differential transcriptional regulation of pri-miR-139 transcripts independent of PDE2A [79]. However, it is likely that one of the mechanisms by which p53 regulates MIR139 expression is via the induction of $P D E 2 A$ expression. PDE2A is already expressed in the absence of p53, which suggests that $\mathrm{p} 53$ may play a role in the processing of intronic pri-miR-139 that occurs after splicing of PDE2A premature mRNA (Figure 1B). The tumor suppressor p53 has been shown to enhance miRNA biogenesis by association with DEAD-Box Helicase-5 (DDX5) in cellular stress responses [80]. Mechanisms other than p53-mediated transcription are involved the regulation of MIR139 expression, which will be discussed in the next section.

\section{MIR139 Expression Is Repressed in Various Types of Cancer}

\subsection{The Expression of MIR139 Is Frequently Silenced in AML}

Acute myeloid leukemia (AML) is a complex disorder of the bone marrow (BM) that results from the aberrant clonal expansion of myeloid progenitors that have acquired genomic aberrations and mutations, which provide a growth advantage and a block of differentiation [81]. In addition, miRNAs are aberrantly expressed in all subtypes of AML [82-84]. We [38,45] and other investigators [46-51] have found that MIR139 is a tumor suppressor gene that is frequently silenced in leukemia, including Fanconi anemia-related leukemia, caused by interstrand crosslink (ICL)-induced DNA damage [45], Breakpoint Cluster Region Protein-Abelson Murine Leukemia Viral Oncogene Homolog 1(BCR-ABL)mediated leukemogenesis [49], AML [46,47] and T-cell acute lymphoblastic leukemia [51]. We found that miR-139 expression levels are low in normal HSPCs and induced by DNA damage [45]. We showed that $m i R-139-3 p$ is not expressed in clinical AML samples. In agreement, analysis of deep sequencing data of AML samples from the Cancer Genome Atlas (TCGA) further indicated that $m i R-139-3 p$ is not expressed or is expressed at low levels in AML [45]. In addition, $m i R-139-5 p$ is undetectable in most AML cases, except for a low expression level in AML samples characterized by a M2 FAB classification and $t(8 ; 21)$, in samples with inv-(16) and some cases with various abnormalities (our unpublished data). Furthermore, $m i R-139-5 p$ is downregulated in different subtypes of AML and in AML cell lines, compared to differentiated myeloid cells, which further supports a role of miR-139-5p as a tumor suppressor [46]. Krowiorz et al. show that $m i R-139-5 p$ is downregulated in FLT-3 mutants, in NPM1/FLT3 double mutants and in CN AML compared to the average expression of all AML samples tested in the TCGA cohort [47]. In this comparison, miR-139 expression in the $t-(9 ; 11)$ cases was very similar to other subtypes of AML. However, we presented strong evidence that MIR139 is downregulated in AML expressing the MLLAF9 oncogene compared to normal HSPCs. Together, these data indicate that the tumor suppressor gene MIR139 is commonly silenced in AML.

\subsection{The Effect of MIR139 KO on Development and Oncogenesis}

To investigate the functions of MIR139 in oncogenesis, we have generated Mir139 knockout (KO) mice [38,43]. We found that C57BL/6J Mir139 KO mice were born at Mendelian ratios, developed normally and had expected HSPC counts and mature hematopoietic cell types in peripheral blood and BM [38,43]. Notably, the expression of Pde2a was not affected in the HSPCs of Mir139 KO mice [38]. A panel of 22 Mir139 KO and 18 Mir139 WT mice were monitored for the development of leukemia and other types of cancer for 2 years. Only one Mir139 KO mouse developed acute leukemia at the age of 89 weeks, suggesting that additional oncogenic driver events are needed for oncogenesis (unpublished data). Clinical data show that acute myeloid leukemia (AML) patients with the lowest miR-139 levels have a poor prognosis [46]. In agreement, we found that Mir139 KO HSPCs gave rise to more and larger colonies when transformed with the MLL-AF9 oncogene in colony-forming unit assays, showing that miR-139-depleted leukemia cells have a growth 
advantage [38]. Whether MIR139 silencing is a critical early driver of leukemogenesis still needs further investigation.

Mir139 KO mice were also used for the investigation of MIR139 tumor suppressor functions in different types of cancer. For instance, other investigators have found that Mir139 KO mice are highly susceptible to the development of dextran sulfate salt (DSS)induced colitis and colon cancer [44]. The investigators found that $m i R-139-5 p$ expression is lost in colorectal cancer tissue over time. The proliferation rate of Mir139 KO tumor cells was enhanced, confirming the growth advantage of Mir139 KO tumor cells. Furthermore, Zhou et al. showed increased expression levels of anti-apoptotic genes $\mathrm{Bcl}-\mathrm{Xl}$ and $\mathrm{Bcl}-2$ in Mir139 KO cells compared to Mir139 WT tumor cells in colitis-associated colorectal cancer [44]. They found that the expression of Mir139 dampens the expression of phosphorylated MAPK, NF- $\mathrm{KB}$ and STAT3, all factors that drive inflammation and colitis-associated oncogenesis [44]. These data demonstrate that MIR139 inactivation is an oncogenic driver event that results in prolonged intracellular stress-induced signaling and the survival of cells.

\subsection{MIR139 Is Silenced by POLR2M Downstream of PRC2 in AML}

Polycomb group (PcG) proteins have been implicated in the silencing of tumor suppressor genes [85-87]. Mounting evidence shows that MIR139 is silenced by the Polycomb repressive complex-2 (PRC2) in various types of cancer [38,70,73,74]. PRC2 consists of the methyltransferase Enhancer of Zeste Homolog-1/2 (EZH1/2), Embryonic Ectoderm Development (EED), Suppressor of Zeste 12 Homolog (SUZ12) and Retinoblastoma-binding protein-4 (RBBP4) [88,89]. EZH1/2 hypermethylates K27 on Histone-H3 (H3K27), which marks silenced genes [90]. Deregulation of PRC2 contributes to AML pathogenesis [91-93]. We have recently identified POLR2M as a novel downstream mediator of PRC2-induced transcriptional repression of MIR139 by interaction with the TSS and enhancer regions of MIR139 (Figure 2A) [38]. POLR2M (also known as GDOWN1) pauses POL-II-mediated transcription by binding to the POL-II complex [94,95]. Promoter-proximal pausing of POL-II at TSSs has been correlated with H3K27me3 and PcG-silenced genes $[96,97]$. We have shown that depletion of POLR2M results in the expression of MIR139 and induction of apoptosis of human and mouse MLL-AF9 AML cells [38]. The repressive activity of POLR2M can be reversed by interaction with the multi-subunit protein complex Mediator, which results in the high induction of transcription [95]. Mediator is a transcriptional co-regulator that consists of approximately 30 subunits, including MED4, MED6, MED7, MED8, MED10, MED11, MED14, MED 17, MED21 and MED22, which are essential for Mediator function [98]. Various Mediator subunits are mutated, aberrantly expressed or deregulated in human cancer including leukemia $[99,100]$. For example, MED12 mutations are found in up to $9 \%$ of chronic lymphocytic leukemia (CLL) cases and contribute to the pathogenesis by activating NOTCH signaling [101,102]. CDK8 transiently associates with Mediator and controls its activity [98]. The Mediator complex provides communication between active enhancers and promoters by forming a molecular bridge within actively transcribed genes and interacts with transcription factors, POL-II and elongation factors [103-107]. In addition, Mediator binds to acetylated Histones [108]. For instance, H4K16 acetylation inhibits the interaction of MED5 and MED17 to chromatin $[108,109]$. Moreover, H3K27 acetylation correlates with high levels of Mediator complex subunits at regular and super enhancers with high POL-II occupancy $[79,110,111]$. Proteomics studies in yeast revealed that 17 subunits of the Mediator complex are dynamically phosphorylated by an unidentified kinase in response to stress and regulate the expression of stress-induced genes [112] (for review, see [98]). Vice versa, there is evidence that the phosphorylation of transcription factor ELK in response to ERK activation fine-tunes the interaction with Mediator and thereby transcriptional activity [113]. However, how Mediator interacts with other transcription factors to facilitate the transcription of MIR139 remains elusive. 
A)

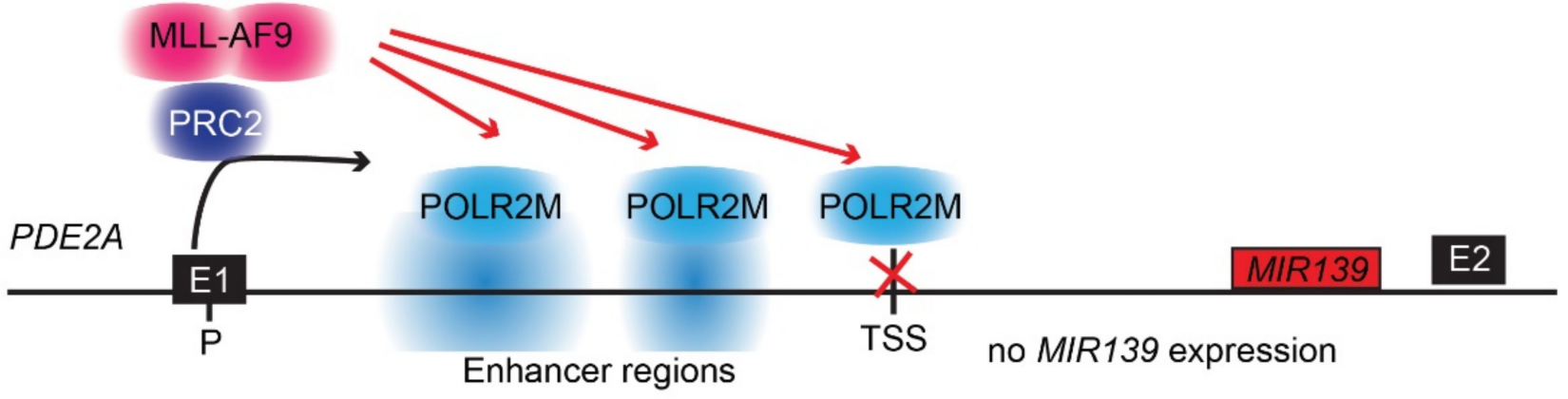

B)

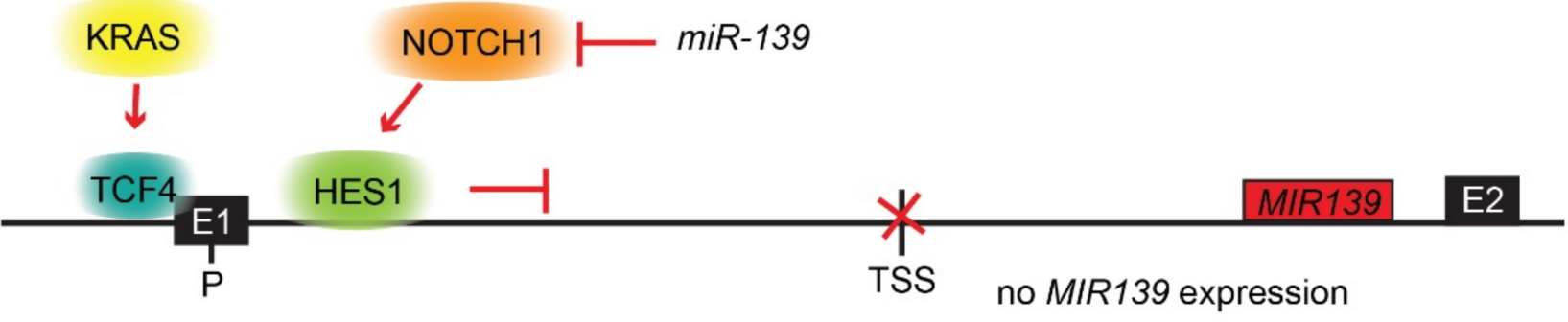

C)
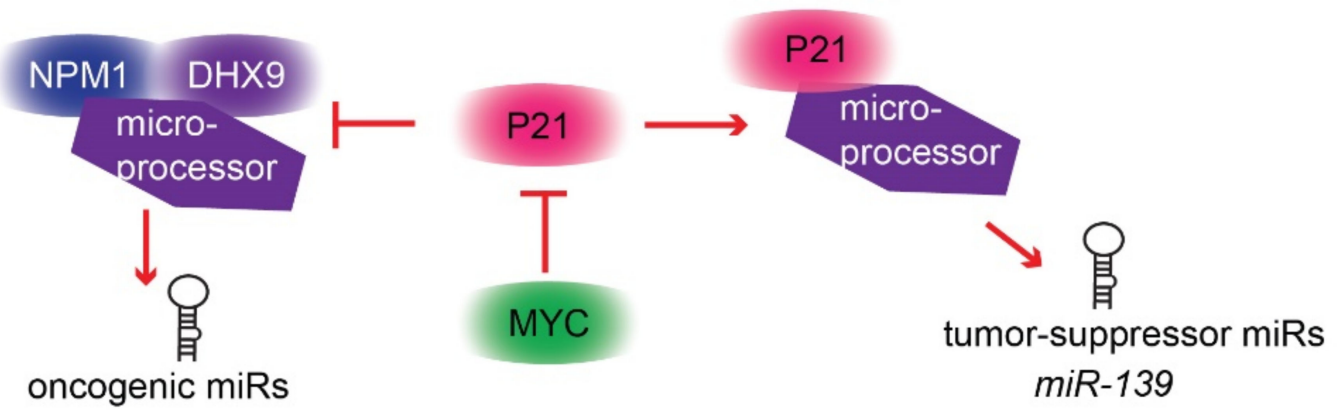

Figure 2. Overview of MIR139 molecular silencing mechanisms. (A) Model of MIR139-silencing mechanism in AML. PRC2 is recruited to the promoter region of PDE2A downstream of MLLAF9. The host gene PDE2A is expressed at normal levels (black arrow). However, under these conditions, POLR2M is recruited to the enhancer regions and to the TSS of MIR139 (red arrows), which results in transcriptional silencing of MIR139 (red cross). (B) Additional silencing mechanisms of MIR139. Mutant KRAS recruits TCF4- $\beta$-CATENIN to the TSS of MIR139, thereby inhibiting transcription. Activated NOTCH1 signaling results in HES1 binding close to the promoter of PDE2A, which causes downregulation of MIR139 expression. NOTCH1 is a validated target of miR-139 (red inhibitor arrow), thereby creating a feed-forward loop. (C) P21 is a central player in the regulation of pri-miR-139 processing. Activation of P21 stimulates the processing of tumor suppressor primiRNAs, including pri-miR-139. However, when P21 is repressed by the oncogene MYC (red inhibitor arrow), this results in further stimulation of the microprocessor that is bound by NPM1 and DHX9 to preferentially process oncogenic miRNAs. KRAS-induced MYC transcription activates KMAT expression, which stabilizes NPM1-DHX9 complex, thereby contributing to the enhanced processing of oncogenic miRNAs.

\subsection{Oncogene Mediated MIR139 Silencing}

Multiple well-known oncogenes silence the expression of MIR139 in cancer. For instance, NOTCH1 signaling suppresses MIR139 expression via the transcriptional repressor 
HES1, which binds to the E-box site at position +644 bp in the PDE2A gene in glioma cells (Figure 2B) [67]. In this study, the authors show that miR-139 modulates stemness by inhibiting Wnt/ $\beta$-catenin signaling, which is a hallmark of cancer [67]. As NOTCH1 is a direct target of $m i R-139$ (discussed below), this creates a feedback mechanism that fine-tunes NOTCH1 signaling (Figure 2B).

In colorectal cancer, MIR139 is strongly downregulated in KRAS mutant cells compared to KRASWT cells [55]. In this study, the investigators found that the expression of MIR139 is controlled by two TCF4 sites flanking the TSS of MIR139 (Figure 2B). TCF4 binds to $\beta$-catenin and transcriptionally silences target genes. Furthermore, the investigators found that, in KRAS mutant cells, the MIR139 expression is suppressed in a WNT3Aactivated $\beta$-catenin-TCF4 complex-dependent manner [55]. The expression of MIR139 is inhibited in KRASWT-overexpressing lung tumor cells in a very different way [62]. KRAS overexpression induces the expression of the long non-coding RNA KRAS-InducedMetastasis-Associated-Transcript 1 (KMAT1) by activation of MYC-mediated transcription. KMAT1 induces the processing of oncogenic miRNAs, including $m i R-17, m i R-18$ and $m i R-$ 27, through stabilization of the RNA-binding proteins DExH-Box Helicase 9 (DHX9) and Nucleophosmin-1 (NPM1). NPM1 binds to DHX9, which is part of the microprocessor complex, in a RNA-dependent manner and is involved in the selection of pri-miRNAs for processing [62]. On the other hand, MYC silences CDKN1A (P21), which is a component of the microprocessor complex, by interaction with DROSHA in specific conditions. The authors show that pri-miRNA transcripts of tumor-suppressing miRNAs, including pri-miR-139, are not processed when P21 is transcriptionally silenced by MYC [62]. When P21 is overexpressed, it antagonizes the stimulating effects of DHX9 and NPM1 on the biogenesis of oncogenic miRNAs, whereas the expression of a subset of tumor-suppressing miRNAs, including pri-miR-139, is enhanced. P21 interacts directly with the microprocessor complex and with a subset of pri-miRNAs. In addition, the authors showed that the levels of pre-miR-139 and $m i R-139$ were both dependent on P21 expression, whereas the expression of pri-miR-139 was not [62]. This indicates that P21 is involved in the selective processing of pri-miR-139 by the microprocessor complex (Figure 2C). The abovementioned MIR139 regulatory genes, including KRAS, MYC, NOTCH1 and NPM1, are frequently mutated in leukemia. However, whether the above-described aberrant MIR139 mechanisms play a direct role in leukemogenesis is unknown and needs further investigation.

\subsection{Post-Transcriptional Regulation of MIR139}

Mir139 expression is regulated by a post-transcriptional mechanism. The first indication for the post-transcriptional regulation of pre-miR-139 was found in colorectal cancer samples from patients in which miR-139 was detected at reduced levels, whereas the levels of pre-miR-139 were similar to the expression in normal tissue [79]. These data suggest that DICER or specific RNA-binding proteins, which interact with pre-miR-139 and regulate further processing, are deregulated in colorectal cancer. In addition, our data in MLL-AF9 leukemia, where Pde $2 a$ is normally expressed and spliced but miR-139 levels are strongly decreased, can only be explained by reduced pri-miR-139 stability and/or processing. The following mechanisms may explain this phenomenon. In MLL-AF9 leukemia, P21 is silenced by Inhibitor of DNA binding 1 (ID1), which is critical for MLL-AF9 leukemogenesis $[56,114]$. According to the role for P21 in the selection of pre-miR-139 for further processing as described above, the downregulation of P21 in MLL-AF9 AML may largely explain the low mature miR-139 levels, but this still needs proper validation.

We found that the enhancer regions in intron- 1 of $P d e 2 a$ and upstream of Mir139 are critical for normal Mir139 expression levels [38]. Thus, our results indicate that other still unknown mechanisms interact with the enhancer regions and are involved in Mir139 expression regulation. DROSHA and DGCR8, associated with transcriptional regulators, are thought to be recruited co-transcriptionally and process pri-miRNAs during transcription [115]. Recent data present evidence that super enhancers boost the transcription and 
DROSHA/DGCR8-mediated processing of a subset of cell-specific miRNAs [116]. Whether these interactions exist at the enhancers of MIR139 is currently under investigation.

Downregulation of $m i R-139$ activities in tumors may be due to the overexpression of competing target RNAs, the so-called sponge activity. For instance, LINC00324 overexpression acts as a $m i R-139$ sponge, thereby releasing Insulin-like Growth Factor-1 Receptor (IGF1R) from miR-139 regulation and increasing the IGF1R protein expression in non-smallcell lung cancer [63]. In addition, the $3^{\prime}$-UTR of LNCRNA PCAT6 competes with the $3^{\prime}$-UTR of $B R D 4$ transcripts for $m i R-139$ binding and downregulates $m i R-139$ expression when overexpressed in pituitary adenomas [76]. The levels of miR-139 may also be downregulated by circular RNAs with miR-139 sponge activities. To date, only a few circular RNAs have been reported in the regulation of MIR139. Strikingly, the circular RNAs that are described to have sponge activity against miR-139 contain only one binding site for either miR-139-5p or $m i R-139-3 p$. To be able to compete with other mRNAs containing sites for miR-139 in their $3^{\prime}$-UTR, the expression of functional circular RNAs should be at least higher than the target mRNA. For instance, Circ-0038718 consists of exons 2 and 3 derived from the gene encoding the Interleukin-4 Receptor (IL4R) and is highly overexpressed in hepatocellular carcinoma [75]. Circ-0038718 contains one miR-139-3p binding site and interacts with AGO2-loaded miR-139-3p, thereby competing for oncogenic miR-139-3p mRNA targets. Furthermore, CircKIF $4 A$ acts as a sponge for $m i R-139-3 p$ in glioma, thereby activating oncogenic WNT3A signaling [68]. In addition, Circ-0000218 controls miR-139-3p levels in a very similar way in laryngeal and colorectal cancer $[57,77]$. CircBACH2 is a circular RNA that is expressed at elevated levels in papillary thyroid carcinoma and downregulates the expression of $m i R-139-5 p$ [78]. How the interaction of AGO2-loaded miR-139 with circular RNA causes degradation of the miRNA is unknown. However, mechanisms by which miRNA-target mRNAs degrade miRNAs have been described [117]. Furthermore, how the increased expression of non-coding RNA or circular RNA, containing only one interaction site, competes with all other $m i R-139$ targets in such a way that it efficiently represses the activity of $m i R-139$ on other target mRNAs is not well understood and suggests a specific RNA-mediated miRNA degradation pathway. An overview of miR-139 regulators is given in Table 2.

Table 2. Overview of Activators and Repressors of MIR139 Expression.

\begin{tabular}{|c|c|c|c|c|}
\hline Regulator of MIR139 & Activator/Repressor & Type of Cells & miR-139 Targets & References \\
\hline $\begin{array}{c}\text { PDE2A } \\
\text { (host gene) }\end{array}$ & Activator & Lung cancer cell lines & & {$[40]$} \\
\hline Epigenetic & Repressor & AML & EIF4G2, BTG3 & [46] \\
\hline PRC2 & Repressor & AML & EIF4G2, HPGD, PTPRT & {$[38,70,73,74]$} \\
\hline POLR2M & Repressor & AML & EIF4G2, HPGD, PTPRT & [38] \\
\hline P53 & Activator & $\begin{array}{l}\text { HSPCs Fanconi anemia } \\
\text { Colon cancer }\end{array}$ & $\begin{array}{c}\text { ELAVL1 } \\
\text { PDE } 4 D \\
\text { P53 targets }\end{array}$ & $\begin{array}{c}{[45]} \\
{[52]} \\
{[53,54]}\end{array}$ \\
\hline NOTCH1/HES1 & Repressor & Glioma & \multirow{3}{*}{$\begin{array}{c}\text { Wnt } / \beta-\text {-Catenin } \\
\text { JUN, DVL1, CTNNB1, } \\
\text { ZEB1 }\end{array}$} & [67] \\
\hline TCF4 & Repressor & Colorectal cancer & & [55] \\
\hline $\begin{array}{l}\text { KRAS/MYC/P21 } \\
\text { Competing RNAs: }\end{array}$ & Repressor & Lung cancer & & [62] \\
\hline LINC00324 & \multirow{6}{*}{ Repressors } & Non-small-cell lung cancer & $I G F 1 R$ & [63] \\
\hline PCAT6 & & Pituitary adenomas & $B R D 4$ & [76] \\
\hline $\begin{array}{c}\text { Circ-0038718 } \\
\text { CircKIF } 4 A\end{array}$ & & $\begin{array}{l}\text { Hepatocellular carcinoma } \\
\text { Glioma }\end{array}$ & WNT3A & [68] \\
\hline Circ-0000218 & & Laryngeal/Colorectal cancer & $R A B 5 A, R A B 1 A$ & {$[57,77]$} \\
\hline CircBACH & & Papillary thyroid carcinoma & LMO4 & {$[78]$} \\
\hline SNHG3 & & Ovarian cancer & NOTCH1 & [71] \\
\hline
\end{tabular}




\section{MIR139 Targets Involved in Oncogenesis}

Overexpression of MIR139 in Kasumi-1 and SKNO-1 cells, both AML cell lines with $\mathrm{t}-(8 ; 21)$, and mRNA expression profiling revealed EIF4G2 as one of the most downregulated transcripts [46]. According to Targetscan, the database that lists predicted miRNA targets [118], EIF4G2 has one well-conserved 8-mer site for miR-139-5p in the $3^{\prime}$-UTR. This miR-139-mediated silencing of EIF4G2 was confirmed on the protein level in Kasumi-1 cells [46]. ShRNA-mediated silencing, at least in part, phenocopied the effects of miR-139 expression on the viability and proliferation of Kasumi-1 cells [46]. EIF4G2 mRNA lacking miR-139 binding sites in the $3^{\prime}$-UTR rescued the anti-proliferative and apoptotic effects of $m i R-139$ overexpression in Kasumi cells. We recently confirmed Eif4g2 as a critical target of miR-139 in mouse MLL-AF9 AML [38], suggesting that Eif4g2 is a more common miR-139 target in leukemia. In addition, EIF4G2 has been recently identified as a miR-139 target in other types of cancer, including glioblastoma and colorectal cancer [119,120]. EIF4G2 is important for protein synthesis [121]. Accordingly, MIR139 overexpression resulted in reduced overall protein expression, which may explain the inhibitory effects of miR-139 expression on tumor cell proliferation and survival [46].

There is mounting evidence that miR-139-5p targets NOTCH1 in different cell types, thereby preventing aberrant $\mathrm{NOTCH} 1$ signaling and oncogenic transformation. According to Targetscan, NOTCH1 contains one broadly conserved site for miR-139-5p in the $3^{\prime}$ UTR. This explains that, in cancers with silenced MIR139 expression, the expression of NOTCH1 is increased. Forced expression of miR-139-5p causes the downregulation of NOTCH1 via direct binding to the $3^{\prime}$-UTR in colorectal cancer and inhibits the migration and invasion of tumor cells [58,59]. Increased levels of RP11-59H7.3, a long non-coding RNA that is aberrantly expressed and correlates with poor prognosis of colorectal cancer, compete with NOTCH1 for miR-139 binding, thereby enhancing NOTCH1 oncogenic functions [60]. Another tumor-suppressing activity of miR-139-5p via NOTCH1 repression in colorectal cancer is the prevention of $\mathrm{CD}_{4} 4^{+} / \mathrm{CD} 133^{+}$-associated multidrug resistance [61]. In ovarian cancer, overexpression of the lncRNA SNHG3 competes for miR-139-5p binding, thereby increasing NOTCH1 levels [71]. The authors showed that reduced miR-139-5p expression enhanced the proliferation and migration of ovarian cancer cells. In addition, downregulation of Notch-1 expression and reduced blood glucose levels were observed as a result of oxidative-stress-induced miR-139 expression in the liver cells of diabetic mice [66]. Furthermore, reduced $m i R-139$ levels as a consequence of chronic fine particulate matter (PM 2.5)-induced cellular damage in the lung cause Notch-1 upregulation and EpithelialMesenchymal Transition (EMT) in mice [64]. Vey similar tumor-suppressing activities of miR-139 on NOTCH1 levels, tumor cell growth, EMT and metastasis have been described in a mouse model for glioma [69]. NOTCH1 signaling is frequently deregulated in various types of leukemia [122-124]. Whether MIR139 plays a major role in NOTCH1 signaling during leukemia development remains to be investigated.

Other miR-139 targets that are described in leukemia and some other types of cancer are BTG3 [46], the RNA-binding protein ELAVL1 [45,65,72], Tetraspanin-3 (TSPAN3), MAX Network Transcriptional Repressor (MNT) [48], 15-Hydroxyprostaglandin Dehydrogenase (HPGD) and Protein Tyrosine phosphatase Receptor Type-T (PTPRT) [38]. Although knockout and knockdown studies show the relevance of these downregulated targets for miR-139mediated functions as a tumor suppressor, more in-depth studies are needed for the understanding of their oncogenic role in leukemia.

\section{Conclusions}

Mounting data show that the targeting of miRNAs and their controlled pathways may be a successful approach for anti-cancer treatment [82,125,126]. It becomes increasingly evident that MIR139 is a critical tumor suppressor gene in different types of cancer and that the deregulation of MIR139 transcription, processing or targeting activity inhibits its tumor-suppressive activities. Although the mechanism of MIR139 silencing in various 
types of cancer is not fully unraveled, targeting MIR139 to reactivate its expression is a promising avenue for novel targeted therapies.

Author Contributions: C.J.S., I.v.Z. and S.J.E. wrote the manuscript. All authors have read and agreed to the published version of the manuscript.

Funding: For this work: C.J.S and I.v.Z. were supported by the Dutch Cancer Foundation (KWF), grant no. 10948 .

Institutional Review Board Statement: Not applicable.

Informed Consent Statement: Not applicable.

Data Availability Statement: Not applicable.

Conflicts of Interest: The authors declare no conflict of interest.

\section{References}

1. Handschuh, L. Not Only Mutations Matter: Molecular Picture of Acute Myeloid Leukemia Emerging from Transcriptome Studies. J. Oncol. 2019, 2019, 7239206. [CrossRef] [PubMed]

2. He, C.; Luo, B.; Jiang, N.; Liang, Y.; He, Y.; Zeng, J.; Liu, J.; Zheng, X. OncomiR or antioncomiR: Role of miRNAs in Acute Myeloid Leukemia. Leuk. Lymphoma 2019, 60, 284-294. [CrossRef] [PubMed]

3. Leung, A.K.; Sharp, P.A. MicroRNA functions in stress responses. Mol. Cell 2010, 40, 205-215. [CrossRef] [PubMed]

4. Lee, Y.; Kim, M.; Han, J.; Yeom, K.H.; Lee, S.; Baek, S.H.; Kim, V.N. MicroRNA genes are transcribed by RNA polymerase II. EMBO J. 2004, 23, 4051-4060. [CrossRef] [PubMed]

5. Bartel, D.P. MicroRNAs: Genomics, biogenesis, mechanism, and function. Cell 2004, 116, 281-297. [CrossRef]

6. Bartel, D.P. Metazoan MicroRNAs. Cell 2018, 173, 20-51. [CrossRef]

7. Bartel, D.P. MicroRNAs: Target recognition and regulatory functions. Cell 2009, 136, 215-233. [CrossRef]

8. Stavast, C.J.; Erkeland, S.J. The Non-Canonical Aspects of MicroRNAs: Many Roads to Gene Regulation. Cells 2019, 8, 1465. [CrossRef]

9. $\quad$ Lee, Y.; Ahn, C.; Han, J.; Choi, H.; Kim, J.; Yim, J.; Lee, J.; Provost, P.; Radmark, O.; Kim, S.; et al. The nuclear RNase III Drosha initiates microRNA processing. Nature 2003, 425, 415-419. [CrossRef]

10. Han, J.; Lee, Y.; Yeom, K.H.; Kim, Y.K.; Jin, H.; Kim, V.N. The Drosha-DGCR8 complex in primary microRNA processing. Genes Dev. 2004, 18, 3016-3027. [CrossRef]

11. Denli, A.M.; Tops, B.B.; Plasterk, R.H.; Ketting, R.F.; Hannon, G.J. Processing of primary microRNAs by the Microprocessor complex. Nature 2004, 432, 231-235. [CrossRef] [PubMed]

12. Lund, E.; Guttinger, S.; Calado, A.; Dahlberg, J.E.; Kutay, U. Nuclear export of microRNA precursors. Science 2004, 303, 95-98. [CrossRef] [PubMed]

13. Bohnsack, M.T.; Czaplinski, K.; Gorlich, D. Exportin 5 is a RanGTP-dependent dsRNA-binding protein that mediates nuclear export of pre-miRNAs. RNA 2004, 10, 185-191. [CrossRef] [PubMed]

14. Lee, Y.; Jeon, K.; Lee, J.T.; Kim, S.; Kim, V.N. MicroRNA maturation: Stepwise processing and subcellular localization. EMBO J. 2002, 21, 4663-4670. [CrossRef]

15. Haase, A.D.; Jaskiewicz, L.; Zhang, H.; Laine, S.; Sack, R.; Gatignol, A.; Filipowicz, W. TRBP, a regulator of cellular PKR and HIV-1 virus expression, interacts with Dicer and functions in RNA silencing. EMBO Rep. 2005, 6, 961-967. [CrossRef]

16. Wilson, R.C.; Tambe, A.; Kidwell, M.A.; Noland, C.L.; Schneider, C.P.; Doudna, J.A. Dicer-TRBP complex formation ensures accurate mammalian microRNA biogenesis. Mol. Cell 2015, 57, 397-407. [CrossRef]

17. MacRae, I.J.; Ma, E.; Zhou, M.; Robinson, C.V.; Doudna, J.A. In vitro reconstitution of the human RISC-loading complex. Proc. Natl. Acad. Sci. USA 2008, 105, 512-517. [CrossRef]

18. Ye, X.; Huang, N.; Liu, Y.; Paroo, Z.; Huerta, C.; Li, P.; Chen, S.; Liu, Q.; Zhang, H. Structure of C3PO and mechanism of human RISC activation. Nat. Struct. Mol. Biol. 2011, 18, 650-657. [CrossRef]

19. Iwasaki, S.; Kobayashi, M.; Yoda, M.; Sakaguchi, Y.; Katsuma, S.; Suzuki, T.; Tomari, Y. Hsc70/Hsp90 chaperone machinery mediates ATP-dependent RISC loading of small RNA duplexes. Mol. Cell 2010, 39, 292-299. [CrossRef]

20. Robb, G.B.; Rana, T.M. RNA helicase A interacts with RISC in human cells and functions in RISC loading. Mol. Cell 2007, 26, 523-537. [CrossRef]

21. Kawamata, T.; Seitz, H.; Tomari, Y. Structural determinants of miRNAs for RISC loading and slicer-independent unwinding. Nat. Struct. Mol. Biol. 2009, 16, 953-960. [CrossRef] [PubMed]

22. Kobayashi, H.; Tomari, Y. RISC assembly: Coordination between small RNAs and Argonaute proteins. Biochim. Biophys. Acta 2016, 1859, 71-81. [CrossRef] [PubMed]

23. Lai, E.C. Micro RNAs are complementary to 3' UTR sequence motifs that mediate negative post-transcriptional regulation. Nat. Genet. 2002, 30, 363-364. [CrossRef] [PubMed] 
24. Liu, J.; Carmell, M.A.; Rivas, F.V.; Marsden, C.G.; Thomson, J.M.; Song, J.J.; Hammond, S.M.; Joshua-Tor, L.; Hannon, G.J. Argonaute2 is the catalytic engine of mammalian RNAi. Science 2004, 305, 1437-1441. [CrossRef]

25. Braun, J.E.; Huntzinger, E.; Izaurralde, E. The role of GW182 proteins in miRNA-mediated gene silencing. Adv. Exp. Med. Biol. 2013, 768, 147-163. [PubMed]

26. Huntzinger, E.; Kuzuoglu-Ozturk, D.; Braun, J.E.; Eulalio, A.; Wohlbold, L.; Izaurralde, E. The interactions of GW182 proteins with PABP and deadenylases are required for both translational repression and degradation of miRNA targets. Nucleic Acids Res. 2013, 41, 978-994. [CrossRef]

27. Fabian, M.R.; Sonenberg, N. The mechanics of miRNA-mediated gene silencing: A look under the hood of miRISC. Nat. Struct. Mol. Biol. 2012, 19, 586-593. [CrossRef]

28. Kuzuoglu-Ozturk, D.; Bhandari, D.; Huntzinger, E.; Fauser, M.; Helms, S.; Izaurralde, E. miRISC and the CCR4-NOT complex silence mRNA targets independently of 43 S ribosomal scanning. EMBO J. 2016, 35, 1186-1203. [CrossRef]

29. Pratt, A.J.; MacRae, I.J. The RNA-induced silencing complex: A versatile gene-silencing machine. J. Biol. Chem. 2009, 284, 17897-17901. [CrossRef]

30. Poria, D.K.; Guha, A.; Nandi, I.; Ray, P.S. RNA-binding protein HuR sequesters microRNA-21 to prevent translation repression of proinflammatory tumor suppressor gene programmed cell death 4. Oncogene 2016, 35, 1703-1715. [CrossRef]

31. Nussbacher, J.K.; Yeo, G.W. Systematic Discovery of RNA Binding Proteins that Regulate MicroRNA Levels. Mol Cell 2018, 69, 1005-1016. [CrossRef]

32. Khalili, N.; Nouri-Vaskeh, M.; Hasanpour Segherlou, Z.; Baghbanzadeh, A.; Halimi, M.; Rezaee, H.; Baradaran, B. Diagnostic, prognostic, and therapeutic significance of miR-139-5p in cancers. Life Sci. 2020, 256, 117865. [CrossRef] [PubMed]

33. Chen, J.A.; Yu, Y.; Xue, C.; Chen, X.L.; Cui, G.Y.; Li, J.; Li, K.F.; Ren, Z.G.; Sun, R.R. Low microRNA-139 expression associates with poor prognosis in patients with tumors: A meta-analysis. Hepatobiliary Pancreat. Dis. Int. 2019, 18, 321-331. [CrossRef]

34. Azevedo, M.F.; Faucz, F.R.; Bimpaki, E.; Horvath, A.; Levy, I.; de Alexandre, R.B.; Ahmad, F.; Manganiello, V.; Stratakis, C.A. Clinical and molecular genetics of the phosphodiesterases (PDEs). Endocr. Rev. 2014, 35, 195-233. [CrossRef] [PubMed]

35. Kurelic, R.; Krieg, P.F.; Sonner, J.K.; Bhaiyan, G.; Ramos, G.C.; Frantz, S.; Friese, M.A.; Nikolaev, V.O. Upregulation of Phosphodiesterase 2A Augments T Cell Activation by Changing cGMP/cAMP Cross-Talk. Front. Pharm. 2021, $12,748798$. [CrossRef] [PubMed]

36. Morita, H.; Murata, T.; Shimizu, K.; Okumura, K.; Inui, M.; Tagawa, T. Characterization of phosphodiesterase 2A in human malignant melanoma PMP cells. Oncol. Rep. 2013, 29, 1275-1284. [CrossRef]

37. Assenza, M.R.; Barbagallo, F.; Barrios, F.; Cornacchione, M.; Campolo, F.; Vivarelli, E.; Gianfrilli, D.; Auletta, L.; Soricelli, A.; Isidori, A.M.; et al. Critical role of phosphodiesterase 2A in mouse congenital heart defects. Cardiovasc. Res. 2018, 114, 830-845. [CrossRef]

38. Stavast, C.J.; van Zuijen, I.; Karkoulia, E.; Ozcelik, A.; van Hoven-Beijen, A.; Leon, L.G.; Voerman, J.S.A.; Janssen, G.M.C.; van Veelen, P.A.; Burocziova, M.; et al. The tumor suppressor MIR139 is silenced by POLR2M to promote AML oncogenesis. Leukemia 2021, 1-14. [CrossRef]

39. Barbagallo, F.; Rotilio, V.; Assenza, M.R.; Aguanno, S.; Orsini, T.; Putti, S.; Isidori, A.M.; Lenzi, A.; Naro, F.; De Angelis, L.; et al. PDE2A Is Indispensable for Mouse Liver Development and Hematopoiesis. Int. J. Mol. Sci. 2020, 21, 2902. [CrossRef]

40. Watanabe, K.; Amano, Y.; Ishikawa, R.; Sunohara, M.; Kage, H.; Ichinose, J.; Sano, A.; Nakajima, J.; Fukayama, M.; Yatomi, Y.; et al. Histone methylation-mediated silencing of miR-139 enhances invasion of non-small-cell lung cancer. Cancer Med. 2015, 4, 1573-1582. [CrossRef]

41. Bao, W.; Fu, H.J.; Xie, Q.S.; Wang, L.; Zhang, R.; Guo, Z.Y.; Zhao, J.; Meng, Y.L.; Ren, X.L.; Wang, T.; et al. HER2 interacts with CD44 to up-regulate CXCR4 via epigenetic silencing of microRNA-139 in gastric cancer cells. Gastroenterology 2011, 141, 2076-2087. [CrossRef] [PubMed]

42. Shen, K.; Mao, R.; Ma, L.; Li, Y.; Qiu, Y.; Cui, D.; Le, V.; Yin, P.; Ni, L.; Liu, J. Post-transcriptional regulation of the tumor suppressor miR-139-5p and a network of miR-139-5p-mediated mRNA interactions in colorectal cancer. FEBS J. 2014, 281, 3609-3624. [CrossRef] [PubMed]

43. Hope, J.L.; Zhao, M.; Stairiker, C.J.; Kiernan, C.H.; Carey, A.J.; Mueller, Y.M.; van Meurs, M.; Brouwers-Haspels, I.; Otero, D.C.; Bae, E.A.; et al. MicroRNA-139 Expression Is Dispensable for the Generation of Influenza-Specific CD8 (+) T Cell Responses. J. Immunol. 2022, 208, 603-617. [CrossRef] [PubMed]

44. Zou, F.; Mao, R.; Yang, L.; Lin, S.; Lei, K.; Zheng, Y.; Ding, Y.; Zhang, P.; Cai, G.; Liang, X.; et al. Targeted deletion of miR-139-5p activates MAPK, NF-kappaB and STAT3 signaling and promotes intestinal inflammation and colorectal cancer. FEBS J. 2016, 283, 1438-1452. [CrossRef] [PubMed]

45. Alemdehy, M.F.; Haanstra, J.R.; de Looper, H.W.; van Strien, P.M.; Verhagen-Oldenampsen, J.; Caljouw, Y.; Sanders, M.A.; Hoogenboezem, R.; de Ru, A.H.; Janssen, G.M.; et al. ICL-induced miR139-3p and miR199a-3p have opposite roles in hematopoietic cell expansion and leukemic transformation. Blood 2015, 125, 3937-3948. [CrossRef] [PubMed]

46. Emmrich, S.; Engeland, F.; El-Khatib, M.; Henke, K.; Obulkasim, A.; Schoning, J.; Katsman-Kuipers, J.E.; Michel Zwaan, C.; Pich, A.; Stary, J.; et al. miR-139-5p controls translation in myeloid leukemia through EIF4G2. Oncogene 2016, 35, $1822-1831$. [CrossRef] [PubMed]

47. Krowiorz, K.; Ruschmann, J.; Lai, C.; Ngom, M.; Maetzig, T.; Martins, V.; Scheffold, A.; Schneider, E.; Pochert, N.; Miller, C.; et al. MiR-139-5p is a potent tumor suppressor in adult acute myeloid leukemia. Blood Cancer J. 2016, 6, 508. [CrossRef] 
48. Fu, Y.; Li, L.; Hou, J.; Li, H.; Lv, C.; Yu, H.; Zhang, X.; Xu, M.; Zhang, M.; Meng, H.; et al. miR-139-5p Regulates the Proliferation of Acute Promyelocytic Leukemia Cells by Targeting MNT. J Oncol. 2021, 2021, 5522051. [CrossRef]

49. Choi, J.; Kim, Y.K.; Park, K.; Nah, J.; Yoon, S.S.; Kim, D.W.; Kim, V.N.; Seong, R.H. MicroRNA-139-5p regulates proliferation of hematopoietic progenitors and is repressed during BCR-ABL-mediated leukemogenesis. Blood 2016, 128, 2117-2129. [CrossRef]

50. Zhang, R.; Tang, P.; Wang, F.; Xing, Y.; Jiang, Z.; Chen, S.; Meng, X.; Liu, L.; Cao, W.; Zhao, H.; et al. Tumor suppressor miR-139-5p targets Tspan3 and regulates the progression of acute myeloid leukemia through the PI3K/Akt pathway. J. Cell Biochem. 2019, 120, 4423-4432. [CrossRef]

51. Qin, L.; Deng, H.Y.; Chen, S.J.; Wei, W.; Zhang, Y.T. miR-139 acts as a tumor suppressor in T-cell acute lymphoblastic leukemia by targeting CX chemokine receptor 4. Am. J. Transl. Res. 2017, 9, 4059-4070.

52. Cao, B.; Wang, K.; Liao, J.M.; Zhou, X.; Liao, P.; Zeng, S.X.; He, M.; Chen, L.; He, Y.; Li, W.; et al. Inactivation of oncogenic cAMP-specific phosphodiesterase 4D by miR-139-5p in response to p53 activation. Elife 2016, 5, e15978. [CrossRef] [PubMed]

53. Cabrita, M.A.; Vanzyl, E.J.; Hamill, J.D.; Pan, E.; Marcellus, K.A.; Tolls, V.J.; Alonzi, R.C.; Pastic, A.; Rambo, T.M.; Sayed, H.; et al. A Temperature Sensitive Variant of p53 Drives p53-Dependent MicroRNA Expression without Evidence of Widespread PostTranscriptional Gene Silencing. PLoS ONE 2016, 11, 0148529. [CrossRef] [PubMed]

54. Cabrita, M.A.; Bose, R.; Vanzyl, E.J.; Pastic, A.; Marcellus, K.A.; Pan, E.; Hamill, J.D.; McKay, B.C. The p53 protein induces stable miRNAs that have the potential to modify subsequent p53 responses. Gene 2017, 608, 86-94. [CrossRef] [PubMed]

55. Du, F.; Cao, T.; Xie, H.; Li, T.; Sun, L.; Liu, H.; Guo, H.; Wang, X.; Liu, Q.; Kim, T.; et al. KRAS Mutation-Responsive miR-139-5p inhibits Colorectal Cancer Progression and is repressed by Wnt Signaling. Theranostics 2020, 10, 7335-7350. [CrossRef] [PubMed]

56. O'Brien, C.A.; Kreso, A.; Ryan, P.; Hermans, K.G.; Gibson, L.; Wang, Y.; Tsatsanis, A.; Gallinger, S.; Dick, J.E. ID1 and ID3 regulate the self-renewal capacity of human colon cancer-initiating cells through p21. Cancer Cell 2012, 21, 777-792. [CrossRef] [PubMed]

57. Pei, F.L.; Cao, M.Z.; Li, Y.F. Circ_0000218 plays a carcinogenic role in colorectal cancer progression by regulating miR-1393p/RAB1A axis. J. Biochem. 2020, 167, 55-65. [CrossRef]

58. Song, M.; Yin, Y.; Zhang, J.; Zhang, B.; Bian, Z.; Quan, C.; Zhou, L.; Hu, Y.; Wang, Q.; Ni, S.; et al. MiR-139-5p inhibits migration and invasion of colorectal cancer by downregulating AMFR and NOTCH1. Protein Cell 2014, 5, 851-861. [CrossRef]

59. Zhang, L.; Dong, Y.; Zhu, N.; Tsoi, H.; Zhao, Z.; Wu, C.W.; Wang, K.; Zheng, S.; Ng, S.S.; Chan, F.K.; et al. microRNA-139-5p exerts tumor suppressor function by targeting NOTCH1 in colorectal cancer. Mol. Cancer 2014, 13, 124. [CrossRef]

60. Zhu, X.; Luo, C.; Bu, F.; Lin, K.; Zhu, Z. Long non-coding RNA RP11-59H7.3 promotes cell proliferation and invasion metastasis in colorectal cancer by miR-139-5p/NOTCH1-axis. Aging 2020, 12, 11653-11666. [CrossRef]

61. Xu, K.; Shen, K.; Liang, X.; Li, Y.; Nagao, N.; Li, J.; Liu, J.; Yin, P. MiR-139-5p reverses CD44+/CD133+-associated multidrug resistance by downregulating NOTCH1 in colorectal carcinoma cells. Oncotarget 2016, 7, 75118-75129. [CrossRef] [PubMed]

62. Shi, L.; Magee, P.; Fassan, M.; Sahoo, S.; Leong, H.S.; Lee, D.; Sellers, R.; Brulle-Soumare, L.; Cairo, S.; Monteverde, T.; et al. A KRAS-responsive long non-coding RNA controls microRNA processing. Nat. Commun. 2021, 12, 2038. [CrossRef] [PubMed]

63. Zhang, M.; Lin, B.; Liu, Y.; Huang, T.; Chen, M.; Lian, D.; Deng, S.; Zhuang, C. LINC00324 affects non-small cell lung cancer cell proliferation and invasion through regulation of the miR-139-5p/IGF1R axis. Mol. Cell Biochem. 2020, 473, 193-202. [CrossRef] [PubMed]

64. Wang, Y.; Zhong, Y.; Zhang, C.; Liao, J.; Wang, G. PM2.5 downregulates MicroRNA-139-5p and induces EMT in Bronchiolar Epithelium Cells by targeting Notch1. J. Cancer 2020, 11, 5758-5767. [CrossRef] [PubMed]

65. Ni, Z.Z.; He, J.K.; Tang, X.; Tao, Z.; Zhang, Y.; Xie, B. Identification of ELAVL1 gene and miRNA-139-3p involved in the aggressiveness of NSCLC. Eur Rev. Med. Pharm. Sci 2020, 24, 9453-9464.

66. Wei, H.; Huang, L.; Wei, F.; Li, G.; Huang, B.; Li, J.; Cao, C. Up-regulation of miR-139-5p protects diabetic mice from liver tissue damage and oxidative stress through inhibiting Notch signaling pathway. Acta Biochim. Biophys. Sin. 2020, 52, 390-400. [CrossRef]

67. Li, S.Z.; Ren, K.X.; Zhao, J.; Wu, S.; Li, J.; Zang, J.; Fei, Z.; Zhao, J.L. miR-139/PDE2A-Notch1 feedback circuit represses stemness of gliomas by inhibiting Wnt/beta-catenin signaling. Int. J. Biol. Sci. 2021, 17, 3508-3521. [CrossRef]

68. Huo, L.W.; Wang, Y.F.; Bai, X.B.; Zheng, H.L.; Wang, M.D. circKIF4A promotes tumorogenesis of glioma by targeting miR-139-3p to activate Wnt5a signaling. Mol. Med. 2020, 26, 29. [CrossRef]

69. Li, J.; Li, Q.; Lin, L.; Wang, R.; Chen, L.; Du, W.; Jiang, C.; Li, R. Targeting the Notch1 oncogene by miR-139-5p inhibits glioma metastasis and epithelial-mesenchymal transition (EMT). BMC Neurol. 2018, 18, 133. [CrossRef]

70. Wu, D.; Wu, F.; Li, B.; Huang, W.; Wang, D. EZH2 promotes the expression of LPA1 by mediating microRNA-139 promoter methylation to accelerate the development of ovarian cancer. Cancer Cell Int. 2020, 20, 551. [CrossRef]

71. Zhang, L.; Li, G.; Wang, X.; Zhang, Y.; Huang, X.; Wu, H. lncRNA SNHG3 acts as oncogene in ovarian cancer through miR-139-5p and Notch1. Oncol. Lett. 2021, 21, 122. [CrossRef] [PubMed]

72. Xue, F.; Li, Q.R.; Xu, Y.H.; Zhou, H.B. MicroRNA-139-3p Inhibits The Growth And Metastasis Of Ovarian Cancer By Inhibiting ELAVL1. Onco. Targets 2019, 12, 8935-8945. [CrossRef]

73. Ma, J.; Zhang, J.; Weng, Y.C.; Wang, J.C. EZH2-Mediated microRNA-139-5p Regulates Epithelial-Mesenchymal Transition and Lymph Node Metastasis of Pancreatic Cancer. Mol. Cells 2018, 41, 868-880. [PubMed]

74. Au, S.L.; Wong, C.C.; Lee, J.M.; Fan, D.N.; Tsang, F.H.; Ng, I.O.; Wong, C.M. Enhancer of zeste homolog 2 epigenetically silences multiple tumor suppressor microRNAs to promote liver cancer metastasis. Hepatology 2012, 56, 622-631. [CrossRef]

75. Sun, R.; Li, H.; Li, J.; Shen, S.; Cui, G.; Dong, G. CircRNA circ-0038718 promotes hepatocellular carcinoma progression through sponging miR-139-3p. Biochem. Biophys. Res. Commun. 2020, 533, 845-852. [CrossRef] 
76. Zhao, P.; Cheng, J.; Li, B.; Nie, D.; Wang, H.; Li, C.; Gui, S.; Zhang, Y. LncRNA PCAT6 regulates the progression of pituitary adenomas by regulating the miR-139-3p/BRD4 axis. Cancer Cell Int. 2021, 21, 14. [CrossRef]

77. Bai, Y.; Hou, J.; Wang, X.; Geng, L.; Jia, X.; Xiang, L.; Nan, K. Circ_0000218 plays a carcinogenic role in laryngeal cancer through regulating microRNA-139-3p/Smad3 axis. Pathol. Res. Pr. 2020, 216, 153103. [CrossRef]

78. Cai, X.; Zhao, Z.; Dong, J.; Lv, Q.; Yun, B.; Liu, J.; Shen, Y.; Kang, J.; Li, J. Circular RNA circBACH2 plays a role in papillary thyroid carcinoma by sponging miR-139-5p and regulating LMO4 expression. Cell Death Dis. 2019, 10, 184. [CrossRef]

79. Agrawal Singh, S.; Lerdrup, M.; Gomes, A.R.; van de Werken, H.J.; Vilstrup Johansen, J.; Andersson, R.; Sandelin, A.; Helin, K.; Hansen, K. PLZF targets developmental enhancers for activation during osteogenic differentiation of human mesenchymal stem cells. Elife 2019, 8, e40364. [CrossRef]

80. Suzuki, H.I.; Yamagata, K.; Sugimoto, K.; Iwamoto, T.; Kato, S.; Miyazono, K. Modulation of microRNA processing by p53. Nature 2009, 460, 529-533. [CrossRef]

81. Padmakumar, D.; Chandraprabha, V.R.; Gopinath, P.; Vimala Devi, A.R.T.; Anitha, G.R.J.; Sreelatha, M.M.; Padmakumar, A.; Sreedharan, H. A concise review on the molecular genetics of acute myeloid leukemia. Leuk. Res. 2021, 111, 106727. [CrossRef]

82. Bhatnagar, B.; Garzon, R. Clinical Applications of MicroRNAs in Acute Myeloid Leukemia: A Mini-Review. Front. Oncol. 2021, 11, 679022. [CrossRef] [PubMed]

83. Li, M.; Cui, X.; Guan, H. MicroRNAs: Pivotal regulators in acute myeloid leukemia. Ann. Hematol. 2020, 99, 399-412. [CrossRef] [PubMed]

84. Balatti, V.; Croce, C.M. MicroRNA dysregulation and multi-targeted therapy for cancer treatment. Adv. Biol. Regul. 2020, 75, 100669. [CrossRef]

85. Wang, W.; Qin, J.J.; Voruganti, S.; Nag, S.; Zhou, J.; Zhang, R. Polycomb Group (PcG) Proteins and Human Cancers: Multifaceted Functions and Therapeutic Implications. Med. Res. Rev. 2015, 35, 1220-1267. [CrossRef]

86. Huang, X.; Yan, J.; Zhang, M.; Wang, Y.; Chen, Y.; Fu, X.; Wei, R.; Zheng, X.L.; Liu, Z.; Zhang, X.; et al. Targeting Epigenetic Crosstalk as a Therapeutic Strategy for EZH2-Aberrant Solid Tumors. Cell 2018, 175, 186-199.e119. [CrossRef]

87. Zhang, H.; Zhu, D.; Zhang, Z.; Kaluz, S.; Yu, B.; Devi, N.S.; Olson, J.J.; Van Meir, E.G. EZH2 targeting reduces medulloblastoma growth through epigenetic reactivation of the BAI1/p53 tumor suppressor pathway. Oncogene 2020, 39, 1041-1048. [CrossRef]

88. Cao, R.; Wang, L.; Wang, H.; Xia, L.; Erdjument-Bromage, H.; Tempst, P.; Jones, R.S.; Zhang, Y. Role of histone H3 lysine 27 methylation in Polycomb-group silencing. Science 2002, 298, 1039-1043. [CrossRef]

89. Laugesen, A.; Hojfeldt, J.W.; Helin, K. Molecular Mechanisms Directing PRC2 Recruitment and H3K27 Methylation. Mol. Cell 2019, 74, 8-18. [CrossRef]

90. Kuzmichev, A.; Nishioka, K.; Erdjument-Bromage, H.; Tempst, P.; Reinberg, D. Histone methyltransferase activity associated with a human multiprotein complex containing the Enhancer of Zeste protein. Genes Dev. 2002, 16, 2893-2905. [CrossRef]

91. Neff, T.; Sinha, A.U.; Kluk, M.J.; Zhu, N.; Khattab, M.H.; Stein, L.; Xie, H.; Orkin, S.H.; Armstrong, S.A. Polycomb repressive complex 2 is required for MLL-AF9 leukemia. Proc. Natl. Acad. Sci. USA 2012, 109, 5028-5033. [CrossRef] [PubMed]

92. Skoda, R.C.; Schwaller, J. Dual roles of EZH2 in acute myeloid leukemia. J. Exp. Med. 2019, 216, 725-727. [CrossRef] [PubMed]

93. Danis, E.; Yamauchi, T.; Echanique, K.; Haladyna, J.; Kalkur, R.; Riedel, S.; Zhu, N.; Xie, H.; Bernt, K.M.; Orkin, S.H.; et al. Inactivation of Eed impedes MLL-AF9-mediated leukemogenesis through Cdkn2a-dependent and Cdkn2a-independent mechanisms in a murine model. Exp. Hematol. 2015, 43, 930-935. [CrossRef]

94. Jishage, M.; Yu, X.; Shi, Y.; Ganesan, S.J.; Chen, W.Y.; Sali, A.; Chait, B.T.; Asturias, F.J.; Roeder, R.G. Architecture of Pol II (G) and molecular mechanism of transcription regulation by Gdown1. Nat. Struct. Mol. Biol. 2018, 25, 859-867. [CrossRef]

95. Hu, X.; Malik, S.; Negroiu, C.C.; Hubbard, K.; Velalar, C.N.; Hampton, B.; Grosu, D.; Catalano, J.; Roeder, R.G.; Gnatt, A. A Mediator-responsive form of metazoan RNA polymerase II. Proc. Natl. Acad. Sci. USA 2006, 103, 9506-9511. [CrossRef]

96. Liu, J.; Wu, X.; Zhang, H.; Pfeifer, G.P.; Lu, Q. Dynamics of RNA Polymerase II Pausing and Bivalent Histone H3 Methylation during Neuronal Differentiation in Brain Development. Cell Rep. 2017, 20, 1307-1318. [CrossRef]

97. Mantsoki, A.; Devailly, G.; Joshi, A. Dynamics of promoter bivalency and RNAP II pausing in mouse stem and differentiated cells. BMC Dev. Biol. 2018, 18, 2. [CrossRef]

98. Soutourina, J. Transcription regulation by the Mediator complex. Nat. Rev. Mol. Cell Biol 2018, 19, 262-274. [CrossRef]

99. Mrozek, K.; Eisfeld, A.K.; Kohlschmidt, J.; Carroll, A.J.; Walker, C.J.; Nicolet, D.; Blachly, J.S.; Bill, M.; Papaioannou, D.; Wang, E.S.; et al. Complex karyotype in de novo acute myeloid leukemia: Typical and atypical subtypes differ molecularly and clinically. Leukemia 2019, 33, 1620-1634. [CrossRef]

100. Zhang, S.; O'Regan, R.; Xu, W. The emerging role of mediator complex subunit 12 in tumorigenesis and response to chemotherapeutics. Cancer 2020, 126, 939-948. [CrossRef]

101. Wu, B.; Slabicki, M.; Sellner, L.; Dietrich, S.; Liu, X.; Jethwa, A.; Hullein, J.; Walther, T.; Wagner, L.; Huang, Z.; et al. MED12 mutations and NOTCH signalling in chronic lymphocytic leukaemia. Br. J. Haematol. 2017, 179, 421-429. [CrossRef] [PubMed]

102. Helbig, D.R.; Abu-Zeinah, G.; Bhavsar, E.; Christos, P.J.; Furman, R.R.; Allan, J.N. Outcomes in CLL patients with NOTCH1 regulatory pathway mutations. Am. J. Hematol 2021, 96, 187-189. [CrossRef] [PubMed]

103. Poss, Z.C.; Ebmeier, C.C.; Taatjes, D.J. The Mediator complex and transcription regulation. Crit. Rev. Biochem. Mol. Biol. 2013, 48, 575-608. [CrossRef] [PubMed]

104. Malik, S.; Roeder, R.G. The metazoan Mediator co-activator complex as an integrative hub for transcriptional regulation. Nat. Rev. Genet. 2010, 11, 761-772. [CrossRef] 
105. Borggrefe, T.; Yue, X. Interactions between subunits of the Mediator complex with gene-specific transcription factors. Semin Cell Dev. Biol. 2011, 22, 759-768. [CrossRef]

106. Takahashi, H.; Parmely, T.J.; Sato, S.; Tomomori-Sato, C.; Banks, C.A.; Kong, S.E.; Szutorisz, H.; Swanson, S.K.; Martin-Brown, S.; Washburn, M.P.; et al. Human mediator subunit MED26 functions as a docking site for transcription elongation factors. Cell 2011, 146, 92-104. [CrossRef]

107. Kagey, M.H.; Newman, J.J.; Bilodeau, S.; Zhan, Y.; Orlando, D.A.; van Berkum, N.L.; Ebmeier, C.C.; Goossens, J.; Rahl, P.B.; Levine, S.S.; et al. Mediator and cohesin connect gene expression and chromatin architecture. Nature 2010, 467, 430-435. [CrossRef]

108. Zhu, X.; Zhang, Y.; Bjornsdottir, G.; Liu, Z.; Quan, A.; Costanzo, M.; Davila Lopez, M.; Westholm, J.O.; Ronne, H.; Boone, C.; et al. Histone modifications influence mediator interactions with chromatin. Nucleic Acids Res. 2011, 39, 8342-8354. [CrossRef]

109. Liu, Z.; Myers, L.C. Med5 (Nut1) and Med17 (Srb4) are direct targets of mediator histone H4 tail interactions. PLoS ONE 2012, 7, e38416.

110. Whyte, W.A.; Orlando, D.A.; Hnisz, D.; Abraham, B.J.; Lin, C.Y.; Kagey, M.H.; Rahl, P.B.; Lee, T.I.; Young, R.A. Master transcription factors and mediator establish super-enhancers at key cell identity genes. Cell 2013, 153, 307-319. [CrossRef]

111. Quevedo, M.; Meert, L.; Dekker, M.R.; Dekkers, D.H.W.; Brandsma, J.H.; van den Berg, D.L.C.; Ozgur, Z.; van IJcken, W.F.J.; Demmers, J.; Fornerod, M.; et al. Publisher Correction: Mediator complex interaction partners organize the transcriptional network that defines neural stem cells. Nat. Commun. 2019, 10, 3318. [CrossRef]

112. Miller, C.; Matic, I.; Maier, K.C.; Schwalb, B.; Roether, S.; Strasser, K.; Tresch, A.; Mann, M.; Cramer, P. Mediator phosphorylation prevents stress response transcription during non-stress conditions. J. Biol. Chem. 2012, 287, 44017-44026. [CrossRef]

113. Mylona, A.; Theillet, F.X.; Foster, C.; Cheng, T.M.; Miralles, F.; Bates, P.A.; Selenko, P.; Treisman, R. Opposing effects of Elk-1 multisite phosphorylation shape its response to ERK activation. Science 2016, 354, 233-237. [CrossRef]

114. Man, N.; Sun, X.J.; Tan, Y.; Garcia-Cao, M.; Liu, F.; Cheng, G.; Hatlen, M.; Xu, H.; Shah, R.; Chastain, N.; et al. Differential role of Id1 in MLL-AF9-driven leukemia based on cell of origin. Blood 2016, 127, 2322-2326. [CrossRef]

115. Morlando, M.; Ballarino, M.; Gromak, N.; Pagano, F.; Bozzoni, I.; Proudfoot, N.J. Primary microRNA transcripts are processed co-transcriptionally. Nat. Struct. Mol. Biol. 2008, 15, 902-909. [CrossRef]

116. Suzuki, H.I.; Young, R.A.; Sharp, P.A. Super-Enhancer-Mediated RNA Processing Revealed by Integrative MicroRNA Network Analysis. Cell 2017, 168, 1000-1014.e1015. [CrossRef]

117. Sheu-Gruttadauria, J.; Pawlica, P.; Klum, S.M.; Wang, S.; Yario, T.A.; Schirle Oakdale, N.T.; Steitz, J.A.; MacRae, I.J. Structural Basis for Target-Directed MicroRNA Degradation. Mol. Cell 2019, 75, 1243-1255.e1247. [CrossRef]

118. Agarwal, V.; Bell, G.W.; Nam, J.W.; Bartel, D.P. Predicting effective microRNA target sites in mammalian mRNAs. Elife 2015, 4, e05005. [CrossRef]

119. Ali, S.R.; Orang, A.; Marri, S.; McKinnon, R.A.; Meech, R.; Michael, M.Z. Integrative Transcriptomic Network Analysis of Butyrate Treated Colorectal Cancer Cells. Cancers 2021, 13, 636. [CrossRef]

120. Chai, Y.; Xie, M. LINC01579 promotes cell proliferation by acting as a ceRNA of miR-139-5p to upregulate EIF4G2 expression in glioblastoma. J. Cell. Physiol. 2019, 234, 23658-23666. [CrossRef]

121. Kar, A.N.; MacGibeny, M.A.; Gervasi, N.M.; Gioio, A.E.; Kaplan, B.B. Intra-axonal synthesis of eukaryotic translation initiation factors regulates local protein synthesis and axon growth in rat sympathetic neurons. J. Neurosci. 2013, 33, 7165-7174. [CrossRef]

122. Kang, K.B.; Lawrence, B.D.; Gao, X.R.; Guaiquil, V.H.; Liu, A.; Rosenblatt, M.I. The Effect of Micro- and Nanoscale Surface Topographies on Silk on Human Corneal Limbal Epithelial Cell Differentiation. Sci. Rep. 2019, 9, 1507. [CrossRef] [PubMed]

123. Zheng, R.; Li, M.; Wang, S.; Liu, Y. Advances of target therapy on NOTCH1 signaling pathway in T-cell acute lymphoblastic leukemia. Exp. Hematol. Oncol. 2020, 9, 31. [CrossRef] [PubMed]

124. Fattizzo, B.; Rosa, J.; Giannotta, J.A.; Baldini, L.; Fracchiolla, N.S. The Physiopathology of T- Cell Acute Lymphoblastic Leukemia: Focus on Molecular Aspects. Front. Oncol 2020, 10, 273. [CrossRef] [PubMed]

125. Chakraborty, C.; Sharma, A.R.; Sharma, G.; Lee, S.S. Therapeutic advances of miRNAs: A preclinical and clinical update. J. Adv. Res. 2021, 28, 127-138. [CrossRef] [PubMed]

126. Rupaimoole, R.; Slack, F.J. MicroRNA therapeutics: Towards a new era for the management of cancer and other diseases. Nat. Rev. Drug Discov. 2017, 16, 203-222. [CrossRef] [PubMed] 